\title{
Amniotic Fluid Cell Cultures
}

\author{
MATILDA M. NELSON and A. E. H. EMERY \\ University Department of Human Genetics, Western General Hospital, Edinburgh
}

Summary. In an 18-month period, 249 samples of amniotic fluid were used experimentally in attempts to enhance success in cell cultures. None of the experimental situations proved entirely satisfactory in this aim. Emphasis is laid on the quality of serum used in culture. Particularly satisfactory serum should be retained for use in amniotic fluid cell cultures which are dependent on unknown growth stimulating factors present only in certain batches of sera.

Amniotic fluid cells have been studied in this laboratory for four years. Culture of amniotic fluid cells was first attempted three years ago. When a satisfactory method was established, work was expanded to cover variables in culture conditions.

\section{Material}

Specimens of amniotic fluid have been obtained at all stages of pregnancy. In early pregnancy, fluid was removed by aspiration from intact sacs removed by hysterotomy for therapeutic abortion or by amniocentesis before installation of hypertonic solutions for induction of abortion. Later in pregnancy all specimens were obtained by transabdominal amniocentesis and the majority of these were for the control of $\mathrm{Rh}$ immunized pregnancies. For experimental purposes, no attempt was made to divide the specimens by gestational age as previous work (Nelson and Emery, 1970) had shown that the overall success rate in culture did not vary significantly between samples of less than 20 weeks or over 20 weeks' gestation.

During the last 18 months 249 samples of amniotic

Received 17 August 1972. fluid provided the experimental material discussed below. No diagnostic specimens were included.

\section{Methods}

Cell Counts. Cell counts using the vital stain trypan blue were carried out on 237 of the 249 experimental cultures with results shown in Table $I$.

Basic Culture Technique. The following method was used for all control cultures. A well mixed sample of amniotic fluid was centrifuged for 10 minutes at 800$900 \mathrm{rpm}$ and the supernatant decanted for other studies. The cells were resuspended in the remaining 0.25 to 0.5 $\mathrm{ml}$ fluid in the centrifuge tube. Fetal calf serum $(0 \cdot 25$ $\mathrm{ml}$ ) was then added to the suspension, either directly into the centrifuge tube or by gentle mixing in the culture dish. The cells were allowed to settle for 5 to 10 minutes before medium was added. Plastic (Falcon) $30 \mathrm{~mm}$ Petri dishes were used and the medium was Eagles MEM supplemented with $30 \%$ fetal calf serum. Penicillin, streptomycin, and fungizone were added as antibiotic and antifungal agents. The dishes were incubated at $36^{\circ} \mathrm{C}$ in a fully humidified atmosphere with added $5 \% \mathrm{CO}_{2}$. Cultures were examined at 3 days. The first medium change was carried out at 7 days and twice weekly thereafter.

TABLE I

CELL COUNTS ON EXPERIMENTAL CULTURES

\begin{tabular}{l|r|r|r|r}
\hline & \multicolumn{2}{|c|}{$\begin{array}{c}\text { Before 20 Weeks' } \\
\text { Gestation }\end{array}$} & \multicolumn{2}{|c}{$\begin{array}{c}\text { After 20 Weeks' } \\
\text { Gestation }\end{array}$} \\
\cline { 2 - 5 } & $\begin{array}{c}\text { Successful } \\
\text { Culture }\end{array}$ & $\begin{array}{c}\text { Unsuccessful } \\
\text { Culture }\end{array}$ & $\begin{array}{c}\text { Successful } \\
\text { Culture }\end{array}$ & $\begin{array}{c}\text { Unsuccessful } \\
\text { Culture }\end{array}$ \\
\hline $\begin{array}{l}\text { Number of specimens cultured } \\
\text { Number of cell counts performed }\end{array}$ & 42 & 36 & 92 & 79 \\
Viable cells per dish & 39 & 34 & 90 & 74 \\
Total cells per dish & 27,900 & 9,100 & 53,900 & 69,000 \\
Viable cells per dish $(\%)$ & 171,200 & 79,600 & 306,800 & 556,900 \\
11 & 16 & 18 & 12 \\
\hline
\end{tabular}


For the purpose of this report, growth is defined as the presence of growing cells of either fibroblastic or epithelioid appearance within the first 14 days of incubation.

Alterations in Culture Dishes. Carrell flasks (15 ml capacity), medical flats of 50, 100, and $200 \mathrm{ml}$ capacity and babies milk feeding bottles were used against $30 \mathrm{~mm}$ plastic Petri dishes as controls.

\section{Results}

Cell Counts. In later pregnancies there were less viable cells in successful cultures whereas in pregnancies of less than 20 weeks' duration, the average number of viable cells was three times as high in successful as in unsuccessful cultures.

It is likely that the overall low average inoculum of cells in these early unsuccessful cultures contributed to their failure to grow, but it is not entirely responsible as there were many satisfactory cultures from smaller inocula. There were 15 samples $(44 \%)$ with zero viable cell counts in the early specimens which did not grow and nine $(23 \%)$ in those which grew. The difference is not statistically significant.

Culture Experiments (Table II). The results are discussed under three headings: plastic versus glass dishes, dishes of different size, and open and closed dishes.

Plastic versus Glass Dishes. In this instance, the aim was to consider whether the cells attached better to the glass than to the plastic surfaces, whether this attachment would have an influence on the rate of initial growth, and whether the inert plastic compared to glass of ordinary composition and somewhat different physical properties had any effect.

There was no overall significant difference in the results (Table II).

A further test was carried out to establish that the amniotic fluid cells did not adhere to the plastic universal containers in which the fluid is transferred to the laboratory. For this, glass universal containers were compared to plastic. Only in the former was there any significant attachment of the cells to the walls of the container and only in these did growth occur.

Dishes of Different Size. Here, the aim was to consider whether larger surface area for attachment of cells would improve growth by allowing more colonies to develop and whether the differences in atmosphere overlying the medium had any effect. In the larger dishes there is a much greater volume of 'atmosphere' overlying the medium which requires to be saturated with water vapour. There is, however, a correspondingly much larger surface area of medium exposed to the atmosphere from which evaporation of water can occur and across which equilibration of $p \mathrm{H}$ will take place. The gaseous equilibration will be in proportion to the volumes concerned in the different sizes of dishes. No significant difference in growth pattern was seen.

In addition, the metabolic alterations due to the presence of cells either attaching and growing, dying or lying quiescent will depend on the proportion of cells present in the volume of medium. The initial inoculum of cells contains a heterogeneous mixture of cells with a very low plating efficiency. In the majority of cases where the initial cell inoculum was such as to give similar proportions of cells in control and test dishes, there was no difference in growth pattern; nor was there any difference in the minority where this adjustment was not carried out. This result had already been anticipated from previous work (Nelson and Emery, 1970).

'Open' and 'Closed' Dishes. The Petri dish lid rests lightly on the bottom portion allowing free access of 'atmosphere' from the external environment to the interior of the dish. The Carrell

TABLE II

EXPERIMENTAL CULTURE DISHES

\begin{tabular}{|c|c|c|c|c|c|c|c|c|}
\hline & \multirow{2}{*}{$\begin{array}{c}\text { Plastic } \\
\text { Petri } \\
\text { Dishes }\end{array}$} & \multirow{2}{*}{$\begin{array}{l}\text { Carrell } \\
\text { Flasks }\end{array}$} & \multicolumn{3}{|c|}{ Medical Flats } & \multirow{2}{*}{$\begin{array}{c}\text { Milk } \\
\text { Bottles }\end{array}$} & \multirow{2}{*}{$\begin{array}{c}\text { Total } \\
\text { in Glass } \\
\text { Cultures }\end{array}$} & \multirow{2}{*}{$\begin{array}{c}\text { Total } \\
\text { Closed } \\
\text { Cultures }\end{array}$} \\
\hline & & & $50 \mathrm{ml}$ & $100 \mathrm{ml}$ & $200 \mathrm{ml}$ & & & \\
\hline $\begin{array}{l}\text { Total volume of dish (ml) } \\
\text { Volume of medium used (ml) } \\
\text { Proportion of volume of atmosphere over- } \\
\text { lying medium to volume of medium } \\
\text { Area of interface surface of medium and } \\
\text { atmosphere }\left(\mathrm{cm}^{2}\right) \\
\text { Cultures which grew at } 14 \text { days (expressed } \\
\text { as percentage of successful culture } \\
\text { growth) }\end{array}$ & $\begin{array}{l}8 \cdot 0 \\
1 \cdot 5 \\
4: 1 \\
6 \cdot 0 \\
75 \cdot 0\end{array}$ & $\begin{array}{r}15 \cdot 0 \\
3 \cdot 0 \\
4: 1 \\
14 \cdot 0 \\
90 \cdot 0\end{array}$ & $\begin{array}{r}54 \cdot 0 \\
5 \cdot 0 \\
10: 1 \\
24 \cdot 0 \\
74 \cdot 0\end{array}$ & $\begin{array}{r}106 \cdot 0 \\
10 \cdot 0 \\
10: 1 \\
52 \cdot 5 \\
50 \cdot 0\end{array}$ & $\begin{array}{r}235 \cdot 0 \\
20 \cdot 0 \\
11: 1 \\
72 \cdot 0 \\
40 \cdot 0\end{array}$ & $\begin{array}{r}285 \cdot 0 \\
20 \cdot 0 \\
13: 1 \\
60 \cdot 0 \\
68 \cdot 0\end{array}$ & 73.0 & $67 \cdot 0$ \\
\hline
\end{tabular}


flasks are closed with sterile gauze and cotton wool plugs which permit free interchange but which filter the atmosphere. The medical flats and milk bottles have screw-on caps with plastic or rubber interliners, which theoretically should provide an air tight lock. It has been found in practice, however, that the screw caps do allow carbon dioxide to enter the bottles within one to two hours in sufficient quantity to cause visible $p \mathrm{H}$ indicator changes. In view of these differing handicaps to free exchange of 'atmosphere', it is interesting to note that the success rate of growth at 14 days or less in the Carrell flasks is significantly greater $(p<0.05)$ than that in the total 'closed' culture flasks, but not when compared to the Petri dishes.

Alteration of Biological Factors (Table III). Four different routine tissue culture supplements were tested.

Fetal Calf Serum. Serum is a routine supplement used in most tissue culture techniques and has been found to be an essential ingredient in the successful growth of amniotic fluid cells. In most cases fetal calf serum has been used, usually in a concentration of $30 \%$. This concentration has been accepted here as the basic control supplement against test supplements of $20 \%$ and $10 \%$. Neither test concentration had a significant result compared with the controls.

Bovine Calf Serum. This again is a recognized supplement but it is usually suggested that either elements are lacking in the serum obtained from newborn calves which have fed or that the serum is toxic due to the production of antibodies by the calves. No significant difference can be seen to be due to the use of this supplement in either $15 \%$ or $10 \%$ concentration.

Tryptose Phosphate Broth. This is used extensively in bacterial culture, it has been used to good effect in some human tissue cultures. The accepted concentration is $1 \%$. Its effect, if any, was very small.

Chicken Embryo Extract. The most important component of the extract is the small molecular fraction which contains a factor which is not a simple amino acid and which stimulates tissues to grow. In these experiments a $10 \%$ concentration of chicken embryo extract was used with only $10 \%$ fetal calf serum supplement. No significant improvement was seen in the growth rate.

Three experimental culture supplements were tested.

Thymine. Timson and Price (1970) were able to increase the number of mitoses in lymphocyte short-term culture by increasing the concentration of thymine in the medium. Their optimum level was $12.6 \mathrm{mg}$ thymine per litre of medium. Eagles ME medium contains no thymine, so for the experiments, thymine was added to give this same concentration as had proved optimal for lymphocytes. It apparently had no effect in stimulating the amniotic fluid cells to grow when used in this concentration.

Dialysed Urine from Leukaemic Patients. Robinson, Stanley, and Metcalf (1969) found a colony stimulating factor for mouse bone marrow cells in sera of normal mice, urine of normal people and, most significantly, in the urine of leukaemic patients. The mouse cells were grown in semisolid agar and would with this factor proliferate to give colonies. As an experimental procedure, we obtained urine from a patient with leukaemia and prepared the colony stimulating factor according to the method of Robinson et al (1969). It was used as a supplement in the routine method in $30 \%$ and $15 \%$ concentration. This was considerably higher than given in the original report $(7.5 \%$ or $0.15 \mathrm{ml}$ urine in

TABLE III

EXPERIMENTAL BIOLOGICAL FACTORS

\begin{tabular}{|c|c|c|c|c|c|c|c|c|c|c|c|c|c|}
\hline & \multicolumn{3}{|c|}{ Calf Serum $\left({ }^{0}{ }_{0}\right)$} & \multicolumn{2}{|c|}{$\begin{array}{c}\text { Calf } \\
\text { Serum }\left(\begin{array}{l}0 \\
0\end{array}\right)\end{array}$} & \multirow{2}{*}{$\begin{array}{c}\text { Tryptose } \\
\text { Phosphate } \\
\text { Broth (\%) } \\
1\end{array}$} & \multirow{2}{*}{$\begin{array}{c}\begin{array}{c}\text { Chicken } \\
\text { Embryo } \\
\text { Extract } \\
\left(\begin{array}{l}0 \\
\gamma\end{array}\right)\end{array} \\
10\end{array}$} & \multirow[t]{2}{*}{$\begin{array}{c}\text { Thymine } \\
(12.6 \mathrm{mg} / 1)\end{array}$} & \multicolumn{2}{|c|}{$\begin{array}{c}\text { Dialysed } \\
\text { Urine }\left(\begin{array}{l}0 \\
0\end{array}\right)\end{array}$} & \multicolumn{2}{|c|}{$\begin{array}{l}\text { Anence- } \\
\text { phalic } \\
\text { Amniotic } \\
\text { Fluid }(\%)\end{array}$} & \multirow[t]{2}{*}{ Total } \\
\hline & 30 & 20 & 10 & 15 & 10 & & & & 30 & 15 & 30 & 15 & \\
\hline $\begin{array}{l}\text { Test cultures } \\
\text { Growth at } 14 \text { days (ex- } \\
\text { pressed as \% of total } \\
\text { growth) } \\
\text { Control cultures }\end{array}$ & - & 60 & 80 & 86 & 67 & 63 & 100 & 67 & 67 & 67 & 37 & 28 & 67 \\
\hline Growth at 14 days & 100 & - & - & 79 & 68 & 67 & 83 & 50 & 83 & 83 & 75 & 75 & 76 \\
\hline
\end{tabular}


$1 \mathrm{ml}$ medium plus $1 \mathrm{ml} 0.6 \%$ agar). It was thought that as the bone marrow cells were actively dividing, the stimulus required would be much less than that required by desquamated amniotic fluid cells. There was no sign of colony stimulation in the amniotic fluid cell cultures, but there was a very definite increase in the number of cells attaching to the surface of the dish.

Amniotic Fluid. Bovine amniotic fluid is used as an adjuvant to culture medium for some tissues. It was decided to use amniotic fluid from anencephalic pregnancies as cells from such cases had regularly produced extremely good growth. The amniotic fluid was filtered to remove cells and debris and used in a concentration of $30 \%$ and $15 \%$. No attempt was made to match for maternal or fetal parameters (eg, maternal blood groups or $\mathrm{Rh}$ factor) in the test cultures as these were not known at the time of setting up the experiments. No differences were noted between test and control cultures.

In examining Table III, the fluctuations in the percentage of control cultures which grew is quite noticeable. This had been a marked feature throughout the period since amniotic fluid cultures were started. Fig. 1 shows the overall picture with test periods indicated. The main possible factor influencing the changes in growth is serum.

Though each individual batch of serum as sent out from commercial laboratories has been tested for toxicity against standard lines of cells this is not evidence of the fact that it contains the nonspecific growth stimulating factor; nor is it evidence that it contains this factor in quantity or quality suited to the particular requirements of amniotic fluid cells. It is emphasized, therefore, that each laboratory should retain supplies of a particular batch of serum which has produced good growth and keep it for important cultures. This is already routine in



FIG. 1. Successful growth rate (\%) in amniotic fluid cell cultures over 18 months.

many laboratories. It may be sufficient to use the precious serum only for the initial stages, for once growth has started we have found no marked effect of serum on the growth rate.

We would like to thank the obstetricians who supplied the amniotic fluid and Miss E. Watson and Miss $M$. Matheson who provided expert technical assistance. This work was financed by a grant from the Children's Research Fund.

\section{REFERENCES}

Nelson, M. M. and Emery, A. E. H. (1970). Amniotic fluid cells; prenatal sex prediction and culture. British Medical fournal, 1, 523-526.

Robinson, W. A., Stanley, E. R., and Metcalf, D. (1969). Stimulation of bone marrow colony growth in vitro by human urine. Blood, 33, 396-399.

Timson, J. and Price, D. J. (1970). Use of thymine to increase yield of mitoses in lymphocyte cultures. Lancet, 1, 1397-1398. 